\title{
Karakter Fisiologi dan Pendugaan Heritabilitas Tanaman M1 Bawang Merah (Allium Ascalonicum L.) Hasil Induksi Iradiasi Sinar Gamma
}

\section{(Physiological Characters and Heritability Estimation of M1 Onion (Allium ascalonicum L.) Induced by Gamma Ray Irradiation)}

\author{
L. Alfariatna, F. Kusmiyati, dan S. Anwar \\ Agroecotechnology, Faculty of Animal and Agricultural Sciences, Diponegoro University \\ Tembalang Campus, Semarang 50275 - Indonesia \\ CorrespondingE-mail : likaalf@gmail.com
}

\begin{abstract}
The aim of the research was to determine the physiological characters, heritability estimation, and information of lethal doses $\left(\mathrm{LD}_{50}\right)$ of $\mathrm{M} 1$ onion plant induced by gamma ray irradiation. The research was arranged in monofactor experiment with Complete Randomized Design (CRD) with 6 treatments and 5 replications, each replication consisted of 5 onion bulbs was irradiated by gamma ray of $0,3,6,9$, 12, 15 Gy. Parameters observed were the percentage of germination, chlorophyll content, nitrate reductase activity, heritability estimation and $\mathrm{LD}_{50}$. The data were analyzed by anova and followed by BNT 5\% level. The result showed that irradiation significantly affected chlorophyl content and nitrate reductase activity. LD50 of onion was 7.64 Gy. Heritability value ranged from $52.22-80.51 \%$.

Keywords : Allium ascalonicum L.,irradiation, $\mathrm{LD}_{50}$, heritability
\end{abstract}

\begin{abstract}
ABSTRAK
Penelitian ini bertujuan untuk mengkaji efek iradiasi sinar gamma terhadap karakter fisiologi dan nilai heritabilitas M1 tanaman bawang merah (Allium ascalonicum). Penelitian menggunakan percobaan monofaktor dengan rancangan acak lengkap (RAL) terdiri dari 6 perlakuan iradiasi sinar gamma dengan 5 ulangan, setiap ulangan terdiri dari 5 umbi bawang merah dengan dosis penyinaran $0,3,6,9$, 12, dan 15 Gy. Data yang diperoleh diolah secara statistik menggunakan analisis sidik ragam (anova) dan dilanjutkan uji BNT taraf 5\%. Parameter yang diamati meliputi presentase hidup, kandungan klorofil, aktivitas nitrat reduktase, $\mathrm{LD}_{50}$ dan heritabilitas bawang merah. Hasil penelitian menunjukkan bahwa iradiasi sinar gamma memberikan pengaruh nyata terhadap kandungan klorofil a, klorofil b, klorofil total $(\mathrm{a}+\mathrm{b})$ dan ANR. Nilai $\mathrm{LD}_{50}$ bawang merah adalah 7,64 Gy. Nilai heritabilitas berkisar antara 52,22 $80,51 \%$.

Kata kunci : Allium ascalonicum L., iradiasi gamma, $\mathrm{LD}_{50}$, heritabilitas.
\end{abstract}

\section{PENDAHULUAN}

Bawang merah (Allium ascalonicum L.) merupakan salah satu komoditas sayuran utama yang sangat potensial dan terus mengalami peningkatan permintaan dan konsumsi. Wilayah produksi bawang merah di Indonesia terkonsentrasi di Propinsi Jawa Tengah, Jawa Timur dan Jawa Barat. Badan Pusat Statistik (2015) mencatat produksi bawang merah pada tahun 2014 di Provinsi Jawa Tengah mencapai 519,356 ton, Provinsi Jawa Timur mencapai 293,179 ton dan di Jawa Barat mencapai 130,082 ton.

Pusat Data dan Sistem Informasi Pertanian (2015) mencatat konsumsi bawang merah pada tahun 2011 sebesar 2,36 kg/kapita/tahun dan terus meningkat hingga pada tahun 2014 konsumsinya mencapai 2,49 kg/kapita/tahun. Kendala yang dihadapi dalam pemenuhan kebutuhan bawang 
merah yaitu, (1) bawang merah lebih banyak diperbanyak secara vegetatif melalui organ umbi dibandingkan menggunakan biji. (2) produksi bawang merah dalam negeri masih rendah yaitu 10,22 ton/ha (Taufik, 2015) dibandingkan dengan negara lain seperti Thailand dan Filipina dengan rata-rata produksi 12 ton umbi kering/ha (Departemen Pertanian, 2005). Salah satu penyebabnya adalah kualitas bibit yang rendah dan tidak bersertifikat (Thamrin et al., 2003). Salah satu cara meningkatkan produksi bawang merah adalah dengan merakit tanaman bawang merah dengan meningkatkan keragaman genetik.

Perbanyakan vegetatif yang dilakukan secara terus-menerus dengan jangka waktu yang lama dapat mengakibatkan keragaman genetik yang sempit (Sadhu, 1989). Perbaikan sifat genetik bawang merah umumnya tidak dilakukan dengan persilangan karena kemampuan berbunga yang terbatas khususnya pada penanaman di dataran rendah dan tangkai bunga yang dihasilkan setiap individu sangat terbatas (Permadi, 1995). Keterbatasan bunga bawang merah menyebabkan hibridisasi sulit dilakukan, sehingga pembentukan keragaman dapat dilakukan dengan mutasi, baik mutasi induksi maupun mutasi alami (Syukur et al.,2015). Mutasi dapat mengubah ekspresi genetik pada materi genetik sehingga induksi mutasi fisik dengan iradiasi sinar gamma memungkinkan untuk membentuk sekaligus meningkatkan keanekaragaman genetik tanaman bawang merah.

Mutasi merupakan perubahan pada materi genetik dan menyebabkan perubahan ekspresi. Perubahan dalam struktur gen baik yang terjadi secara buatan maupun spontan dengan menggunakan agensia fisik atau kimia (Jusuf, 2001). Mutasi yang dilakukan secara induksi terdapat proses lanjutan berupa perbanyakan dari hasil mutasi, seleksi mutasi yang solid dan stabil, serta pengujian lapang dan pelepasan varietas (Syukur et al., 2015).Upaya untuk meningkatkan keragaman dengan cara induksi mutasi menyebabkan perubahan ekspresi dalam bahan genetik (RNA atau DNA), baik di tingkat urutan gen (mutasi titik) serta di tingkat kromosom. Mutasi dapat digunakan untuk meningkatkan keragaman genetik sehingga memungkinkan bagi pemulia tanaman membuat seleksi sesuai dengan genotip yang diinginkan (Griffiths et al.,2005).
Sinar gamma merupakan radiasi pengion dan berinteraksi pada atom atau molekul untuk menghasilkan radikal bebas dalam sel. Radikal ini dapat merusak atau memodifikasi komponen penting dari sel tanaman dan telah dilaporkan mempengaruhi morfologi, anatomi, fisiologi tanaman yang terjadi secara berbeda pada tingkat iradiasi. Hal inilah yang menyebabkan perubahan struktur tumbuhan dan metabolisme tanaman (Rahimi dan Bahrani, 2011). Iradiasi sinar gamma menginduksi berbagai karakter fisiologi dan laju biosintesis pada tanaman. Iradiasi pada tanaman dengan dosis tinggi mengganggu keseimbangan hormon, pertukaran gas pada daun, pertukaran air dan aktivitas enzimatik (Hameed et al., 2008). Efek yang ditimbulkan termasuk akumulasi senyawa fenol, laju fotosintesis, modulasi dari susunan antioksidan, perubahan struktur sel tanaman dan metabolisme seperti pembesaran membran tilakoid (Wi et al.,2007).

Penelitian ini bertujuan untuk mengkaji dosis iradiasi sinar gamma terhadap karakter fisiologi dan nilai heritabilitas pada M1 tanaman bawang merah (Allium ascalonicum L.).

\section{Materi}

\section{MATERI DAN METODE}

Penelitian telah dilaksanakan pada bulan Januari - Maret 2017. Penyinaran sinar gamma dilaksanakan di Pusat Aplikasi Isotop dan Radiasi Badan Tenaga Nukilr Nasional (PAIR BATAN), Pasar Jumat, Jakarta. Percobaan dilaksanakan di Laboratorium Fisiologi dan Pemuliaan Tanaman, Fakultas Peternakan dan Pertanian, Universitas Diponegoro, Semarang. Materi yang digunakan antara lain umbi bawang merah varietas Bima Brebes. Media tanam yang digunakan terdiri dari campuran tanah dan pupuk organik. Pupuk organik berupa pupuk kandang ayam dosis 6 ton/ha,pupuk urea $200 \mathrm{~kg} / \mathrm{ha}, 250 \mathrm{~kg} \mathrm{SP}-36 / \mathrm{ha}$, $200 \mathrm{~kg} \mathrm{KCl} \mathrm{kg/ha.}$

\section{Metode}

Penelitian ini menggunakan percobaan monofaktor Rancangan Acak Lengkap (RAL) terdiri dari 6 perlakuan (L0 $=0 \mathrm{~Gy}, \mathrm{~L} 1=3 \mathrm{~Gy}, \mathrm{~L} 2$ $=6 \mathrm{~Gy}, \mathrm{~L} 3=9 \mathrm{~Gy}, \mathrm{~L} 4=12 \mathrm{~Gy}, \mathrm{~L} 5=15 \mathrm{~Gy}$ ) dan 5 ulangan. Setiap satuan percobaan terdiri dari 5 
tanaman. Penelitian terdiri dari beberapa tahap yaitu persiapan bahan tanam umbi bawang merah dan perlakuan iradiasi, penanaman dan pemeliharaan. Tahap persiapan dilakukan dengan menyiapkan pot berukuran $30 \times 30 \mathrm{~cm}$ yang telah berisi campuran tanah dan pupuk kandang sebagai pupuk dasar. Perlakuan iradiasi dilakukan dengan membawa umbi bawang merah ke BATAN untuk diradiasi. Iradiasi yang dilakukan adalah iradiasi tunggal menggunakan Gamma Chamber $4000 \mathrm{~A}$ dengan dosis paparan 0 Gy, 3 Gy, 6 Gy, 9 Gy, 12 Gy dan 15 Gy. Bahan tanam yang telah diradiasi segera dipindahkan ke dalam pot dengan media campuran tanah dan pupuk kandang sebagai pupuk dasar. Tahap pemeliharaan berupa penyiraman dan pemupukan menggunakan Urea $200 \mathrm{~kg} / \mathrm{ha}, \mathrm{KCl} 200 \mathrm{~kg} / \mathrm{ha}, \mathrm{Sp}-36250 \mathrm{~kg} / \mathrm{ha}$ (Sumarni dan Hidayat, 2015).

Parameter yang diamati meliputi presentase hidup tanaman dan nilai $\mathrm{LD}_{50}$, kandungan klorofil daun, nilai aktivitas nitrat reduktase, dan heritabilitas. Analisis kandungan klorofil daun menggunakan metode Sumenda et al. (2011), sedangkan analisis ANR dilakukan sesuai prosedur Hartiko (1987) yang telah dimodifikasi secara in vivo. Heritabilitas diperoleh dengan menggunakan rumus pada Tabel 1 (Syukur et al., 2015).

\section{Analisis Data}

Analisis data dilakukan dengan menggunakan analisis ragam (anova) pada taraf 5\% dan jika terdapat perbedaan akan dilanjutkan dengan uji lanjut BNT. Data yang tidak homogen ditransformasi kedalam bentuk akar kuadrat dan Log10 sebelum dianalisis ragam.

\section{HASIL DAN PEMBAHASAN}

\section{Presentase Hidup dan Lethal Dose 50 (LD $\left.{ }_{50}\right)$}

Presentase hidup bawang merah pada dosis 0 Gy sebesar $100 \%$, dosis 3 Gy sebesar $96 \%$, dosis 6 Gy sebesar $92 \%$, dosis 9 Gy sebesar $20 \%$, dosis 12 Gy sebesar $0 \%$ dan dosis 15 Gy sebesar $0 \%$.

Tabel 1. Analisis ragam dan nilai harapan untuk tanaman bawang merah

\begin{tabular}{|c|c|c|c|c|}
\hline \multicolumn{2}{|c|}{ Sumber keragaman } & $\mathrm{Db}$ & $\begin{array}{r}\text { Kuadrat } \\
\text { Tengah } \\
\end{array}$ & Nilai harapan E (MS) \\
\hline \multirow{3}{*}{\multicolumn{2}{|c|}{$\begin{array}{l}\text { Ulangan } \\
\text { Genotipe/Tanaman } \\
\text { Galat }\end{array}$}} & $(\mathrm{r}-1)$ & & \multirow{3}{*}{$\begin{array}{c}\sigma_{\mathrm{e}}^{2}+\mathrm{r} \sigma_{\mathrm{g}}^{2} \\
\sigma_{\mathrm{e}}^{2}\end{array}$} \\
\hline & & $(g-1)$ & M2 & \\
\hline & & $(\mathrm{n}-1)-((\mathrm{r}-1)+(\mathrm{g}-1))$ & M1 & \\
\hline$\sigma_{\mathrm{e}}^{2}$ & \\
\hline$\sigma_{\mathrm{e}}^{2}+r \sigma_{\mathrm{g}}^{2}$ & \multicolumn{4}{|c|}{$=\mathrm{M} 2$} \\
\hline $\mathrm{M} 1+\mathrm{r} \sigma_{\mathrm{g}}^{2}$ & \multicolumn{4}{|c|}{$\begin{array}{l}=\mathrm{M} 2 \\
=\mathrm{M} 2-\mathrm{M} 1\end{array}$} \\
\hline$r \sigma_{g}^{2}$ & \multicolumn{4}{|c|}{$=\mathrm{M} 2-\mathrm{M} 1$} \\
\hline & \multicolumn{4}{|c|}{$=\frac{\mathrm{M} 2-\mathrm{MI}}{\mathrm{r}}$} \\
\hline \multirow{2}{*}{$\begin{array}{l}\sigma_{p}^{2} \\
h^{2}{ }_{(B S)}\end{array}$} & \multicolumn{4}{|c|}{$\begin{aligned}= & \sigma_{\mathrm{g}}^{2}+\sigma_{\mathrm{e}}^{2} \\
= & \sigma^{2} \mathrm{~g} \times 100 \%\end{aligned}$} \\
\hline & $=\frac{}{\sigma_{p}^{2}}$ & \multicolumn{3}{|c|}{$\sigma_{\mathrm{p}}^{2}$} \\
\hline$h^{2}{ }_{(B S)}$ & \multicolumn{4}{|c|}{ Heritabilitas arti luas } \\
\hline$\sigma_{g}^{2}$ & \multicolumn{4}{|c|}{ Ragam genotipe/tanaman } \\
\hline$\sigma_{e}^{2}$ & \multicolumn{4}{|c|}{ Ragam lingkungan } \\
\hline$\sigma_{p}^{2}$ & \multicolumn{4}{|c|}{ Ragam fenotipe } \\
\hline $\mathrm{R}$ & \multicolumn{4}{|c|}{ Ulangan } \\
\hline
\end{tabular}


Perlakuan dosis 12 Gy, dan 15 Gy hanya bertahan hidup sampai 2 MST sedangkan dosis 9 Gy hanya terdapat 5 tanaman yang bertahan hidup sampai masa panen namun tidak mampu menghasilkan umbi. Gejala yang ditunjukkan tanaman ditandai dengan daun menguning dimulai dari ujung daun, layu, mengering kemudian tanaman mati. Hasil pengamatan presentase tumbuh bawang merah tersaji pada Ilustrasi 1.

Presentase tumbuh bawang merah pada dosis $0,3,6,9,12,15$ Gy tiga dosis iradiasi sinar gamma menujukkan bahwa semakin tinggi dosis iradiasi presentase hidup tanaman semakin menurun. Hal ini diduga disebabkan oleh sinar gamma mengganggu aktifitas sintesis protein yang berperan dalam fase perkecambahan. Menurut Pellegrini et al. (2000) penyinaran sinar gamma dosis 10,30, 60, 90, 150 Gy menghambat perkecambahan umbi bawang putih. Abdel-Hady et al.(2008) menyatakan bahwa peningkatan jumlah kematian tanaman disebabkan oleh sinar gamma pada perkecambahan mungkin mempengaruhi aktifitas RNA atau sintesis protein yang berperan dalam tahap awal perkecambahan setelah bibit diiradiasi.

Persamaan hasil curve-fit analysis 4.0 menghasilkan persamaan matematika $\mathrm{y}=12,897-$ $0,105 x$ sehingga diperoleh estimasi $\mathrm{LD}_{50}$ sebesar 7,64Gy. Kurva Linear Fit LD50 tersaji pada Ilustrasi 2.

Radiosensitivitas yang tinggi mampu menyebabkan terbentuknya mutan letal, Datta (2001) selain dengan $\mathrm{LD}_{50}$, radiosensitivitas atau tingkat sensitivitas jaringan terhadap radiasi dapat diamati dari adanya hambatan pertumbuhan atau letalitas. Abdullah et al. (2009) menyatakan bahwa kisaran dosis $\mathrm{LD}_{50}$ berguna untuk memprediksi konsentrasi atau dosis yang sesuai untuk menginduksi mutasi. Menurut Sudrajat dan Zanzibar (2009) iradiasi yang dilakukan pada kisaran dosis yang menyebabkan $50 \%$ kematian dengan pertimbangan bahwa kerusakan fisiologis berimbang dengan perubahan genetik yang diperoleh. Berdasarkan persentase hidup tanaman bawang di atas, maka untuk evaluasi parameter selanjutnya (karakter fisiologi dan nilai
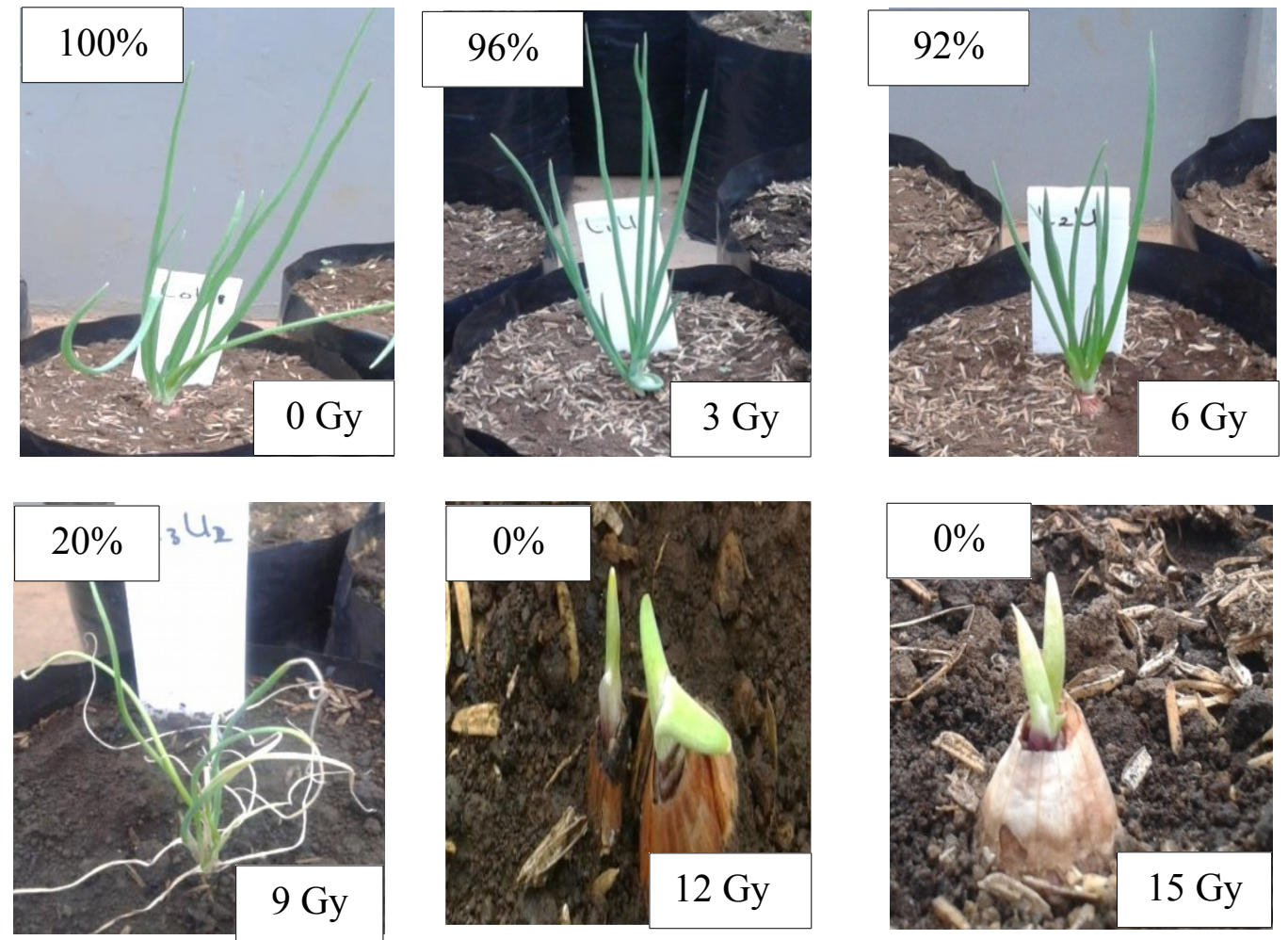

Ilustrasi 1. Penampilan Bawang Merah (Allium ascalonicum L.) Akibat Pemberian Beberapa Dosis Sinar Gamma. 


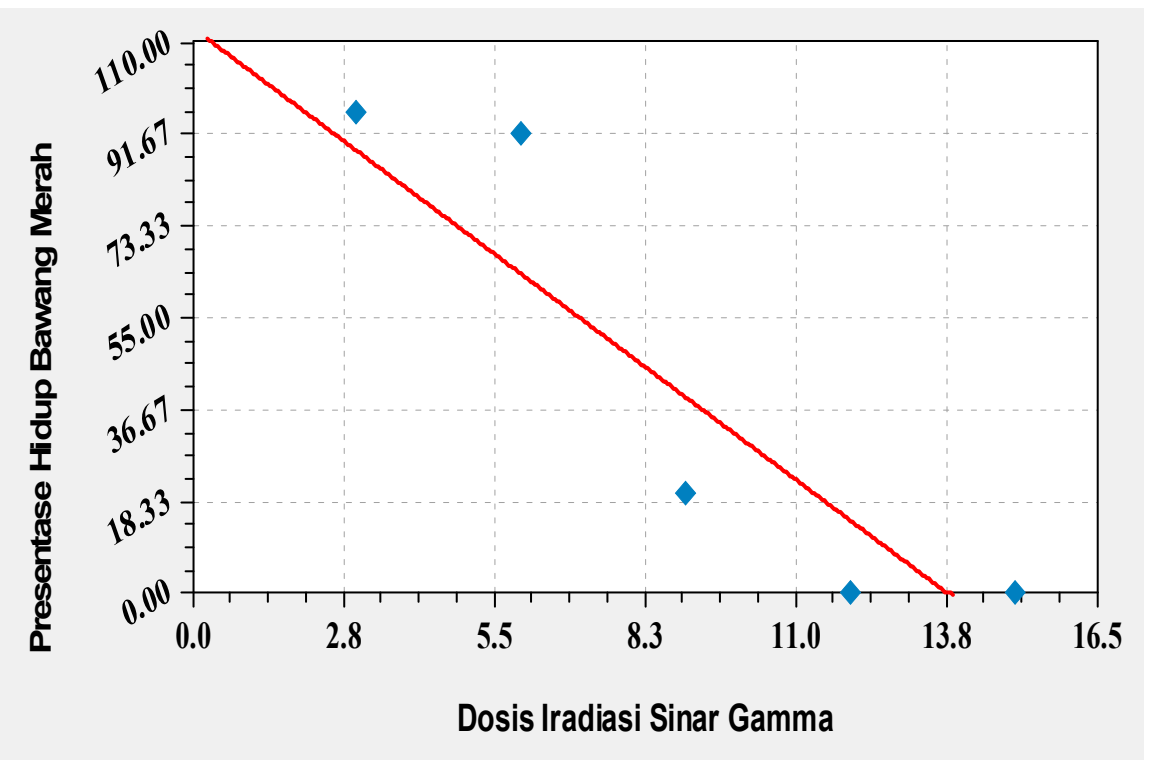

Ilustrasi 2. Kurva Linear Fit $L D_{50}$.

heritabilitas) menggunakan data dengan perlakuan 0,3 , dan 6 Gy saja.

\section{Karakter Fisiologi}

Hasil analisis ragam menunjukkan bahwa dosis iradiasi sinar gamma berpengaruh nyata terhadap ANR, kandungan klorofil a, klorofil b, dan klorofil total $(a+b)$. Perlakuan iradiasi sinar gamma dosis 3 Gy dan 6 Gy tidak berbeda nyata terhadap kandungan klorofil a bawang merah, namun berbeda nyata dengan dosis 0 Gy. Kandungan klorofil a dosis 3 Gy dan dosis 6 Gy lebih besar dibandingkan dosis 0 Gy. Iradiasi sinar gamma dosis 3 Gy dan 6 Gy tidak berbeda nyata terhadap kandungan klorofil b bawang merah, namun berbeda nyata dengan dosis 0 Gy.Kandungan klorofil bdosis 3 Gy dan dosis 6 Gy lebih tinggi dibandingkan dosis 0 Gy. Iradiasi sinar gamma dosis 3 Gy dan dosis 6 Gy tidak berbeda nyata terhadap kandungan klorofil total $(\mathrm{a}+\mathrm{b})$ bawang merah, namun berbeda nyata dengan dosis 0 Gy. Kandungan klorofil total $(\mathrm{a}+\mathrm{b})$ dosis 3 Gy dan 6 Gy lebih tinggi dibandingkan dosis 0 Gy. ANR, kandungan klorofil a, klorofil $b$, dan klorofil total $(\mathrm{a}+\mathrm{b})$ tersaji pada Tabel 2.

Kandungan klorofil dosis 3 Gy dan 6 Gy lebih tinggi dibandingkan 0 Gy menunjukkan bahwa dosis tersebut dapat meningkatkan kandungan klorofil bawang merah. Menurut Wi et al. (2007) efek yang ditimbulkan oleh penyinaran iradiasi gamma termasuk perubahan struktur sel

Tabel 2. Rekapitulasi Sidik Ragam Pengaruh Dosis Sinar Gamma terhadap Karakter Fisiologi Bawang Merah

\begin{tabular}{llrrr}
\hline \hline Parameter & F & 0 Gy & 3 Gy & 6 Gy \\
\hline Klorofil a $(\mathrm{mg} / \mathrm{g})$ & $*$ & $0,08^{\mathrm{b}}$ & $0,20^{\mathrm{a}}$ & $0,26^{\mathrm{a}}$ \\
Klorofil b $(\mathrm{mg} / \mathrm{g})$ & $*$ & $0,07^{\mathrm{b}}$ & $0,17^{\mathrm{a}}$ & $0,13^{\mathrm{a}}$ \\
Klorofil total $(\mathrm{a}+\mathrm{b})(\mathrm{mg} / \mathrm{g})$ & $*$ & $0,15^{\mathrm{b}}$ & $0,37^{\mathrm{a}}$ & $0,39^{\mathrm{a}}$ \\
ANR $(\mathrm{mol} \mathrm{NO} / \mathrm{gram} / \mathrm{jam})$ & $*$ & $15,98^{\mathrm{b}}$ & $43,69^{\mathrm{a}}$ & $40,82^{\mathrm{a}}$ \\
\hline
\end{tabular}

Superskrip berbeda pada baris yang sama menunjukkan perbedaan nyata $(\mathrm{P}<0,005)$. 
tanaman dan metabolisme seperti pembesaran membran tilakoid. Mutasi yang terjadi pada klorofil dimungkinkan adanya mutasi yang terjadi di dalam genom inti. Sugimoto et al. (2004) menyatakan bahwa genom inti mengkode protein kloroplas. Diferensiasi kloroplas terjadi karena impor protein yang dikodekan oleh genom inti serta sitoplasma yang terlibat dalam penargetan protein, sehingga kloroplas membutuhkan koordinasi ekspresi dari gen-gen inti.

Perlakuan iradiasi sinar gamma menunjukkan bahwa dosis 3 Gy dan dosis 6 Gy tidak berbeda nyata terhadap ANR bawang merah, namun berbeda nyata dengan dosis 0 Gy. ANR dosis 0 Gy lebih kecil dibandingkan dosis 3 Gy dan 6 Gy. Peningkatan aktivitas nitrat reduktase pada dosis 3 Gy dan 6 Gy diduga karena induksi sinar gamma masuk ke dalam rantai polipeptida yang disandi oleh gen inti dalam sel, Salisbury dan Ross (1995) menyatakan bahwa reaksi reduksi nitrat yang dikatalisis oleh nitrat reduksate terjadi dalam sitosol di luar setiap organela. NR terdiri dari dua subunit rantai polipeptida yang kembar dan disandi oleh gen inti di dalam sel. Wang et al. (2017) ANR pada tanaman mutan Arabidobsis tidak terdeteksi karena mutan tersebut tidak dapat menggunakan nitrat sebagai satu-satunya sumber nitrogen. Tanaman arabidobsis diinduksi oleh mutagen kimia 2,5 $\mathrm{mM} \mathrm{NH}_{4}$-succinate, 2,5 $\mathrm{mM}$ $\mathrm{NH}_{4} \mathrm{NO}_{3}$, dan $5 \mathrm{mM} \mathrm{KNO}_{3}$.

\section{Pendugaan Heritabilitas}

Hasil analisis ragam menunjukkan bahwa pada semua karakter yaitu klorofil a, klorofil b, klorofil total $(\mathrm{a}+\mathrm{b})$, dan ANR memiliki nilai heritabilitas lebih dari $50 \%$. Hasil perhitungan heritabilitas bawang merah hasil iradiasi sinar gamma tersaji pada Tabel 3 .
Kandungan klorofil a, klorofil b, klorofil total $(\mathrm{a}+\mathrm{b})$, dan ANR memiliki nilai dugaan heritabilitas tinggi yaitu $>50 \%$. Heritabilitas tinggi menunjukkan bahwa pengaruh genetik lebih dominan dibandingkan pengaruh lingkungan sehingga dapat dilakukan seleksi berdasarkan karakter tersebut. Syukur et al. (2015) menyatakan bahwa pendugaan nilai heritabilitas digunakan untuk melihat peranan faktor genetik relatif terhadap faktor lingkungan dalam memberikan penampilan akhir atau fenotipe yang diamati. Menurut Nura (2015) nilai heritabilitas sangat bermanfaat dalam proses seleksi. Seleksi akan efektif apabila suatu populasi memiliki nilai heritabilitas yang tinggi. Menurut Roy (2000) keberhasilan seleksi sangat ditentukan oleh adanya keragaman yang dikendalikan oleh faktor genetik. Hal ini sejalan dengan pendapat Nura et al. (2015) bahwa nilai heritabilitas merupakan komponen genetik yang menunjukkan seberapa besar suatu sifat diturunkan kepada turunannya. Nilai rendah hingga medium menunjukkan bahwa tingginya pengaruh faktor lingkungan jika dibandingkan dengan faktor genetiknya, sedangkan nilai tinggi menunjukkan bahwa tingginya penharuh faktor genetik dibandingkan dengan faktor lingkungan.

\section{Keragaman Bawang Merah}

Hasil analisis klaster 75 tanaman asal bawang merah setelah diiradiasi sinar gamma terbagi ke dalam dua kelompok pada jarak taksonomi 25. Hasil dari dendogram atau pohon filogenik menunjukkan keragaman yang rendah pada karakter klorofil a, klorofil b, klorofil total $(\mathrm{a}+\mathrm{b})$ dan ANR. Dendogram tersebut menunjukkan hanya terdapat 2 kelompok utama pada jarak takson 25 yang menunjukkan kedekatan antar klon. Dua kelompok tersebut

Tabel 3. Nilai Dugaan Heritabilitas (HE) Bawang Merah

\begin{tabular}{lrllcc}
\hline \hline \multicolumn{1}{c}{ Parameter } & CV (\%) & Ragam E & \multicolumn{1}{c}{ Ragam G } & He (\%) & Kriteria \\
\hline Klorofil a & 0,67 & 0,0000464 & 0,00005072 & 52,22 & Tinggi \\
Klorofil b & 0,41 & 0,0000172 & 0,00001956 & 53,21 & Tinggi \\
Klorofil a+b & 1,01 & 0,0001 & 0,00014 & 58,33 & Tinggi \\
ANR & 16,70 & 0,067 & 0,2768 & 80,51 & Tinggi \\
\hline
\end{tabular}

Keterangan : $\mathrm{HE}_{\mathrm{bs}} \leq 20 \%$ (rendah), $20 \% \leq \mathrm{HE}_{\mathrm{bs}} \leq 50 \%$ (sedang), $\mathrm{HE}_{\mathrm{bs}}>50 \%$ (tinggi), Ragam-E (Ragam lingkungan), Ragam-G (Ragam genotipe). 
yaitu kelompok A dan kelompok B. Kelompok B kemudian membentuk dua sub kelompok besar yaitu kelompok C dan D. Kelompok A hanya terdiri dari satu tanaman yaitu tanaman nomor 59 yang merupakan tanaman yang tergolong ekstrim karena memisah dari klon klon lain. Kelompok B terdiri dari 74 nomor tanaman, namun hanya terdapat empat nomor tanaman yang tergolong ekstrim yaitu 1 nomor tanaman pada kelompok C dan 3 nomor tanaman pada kelompok D. Tanaman

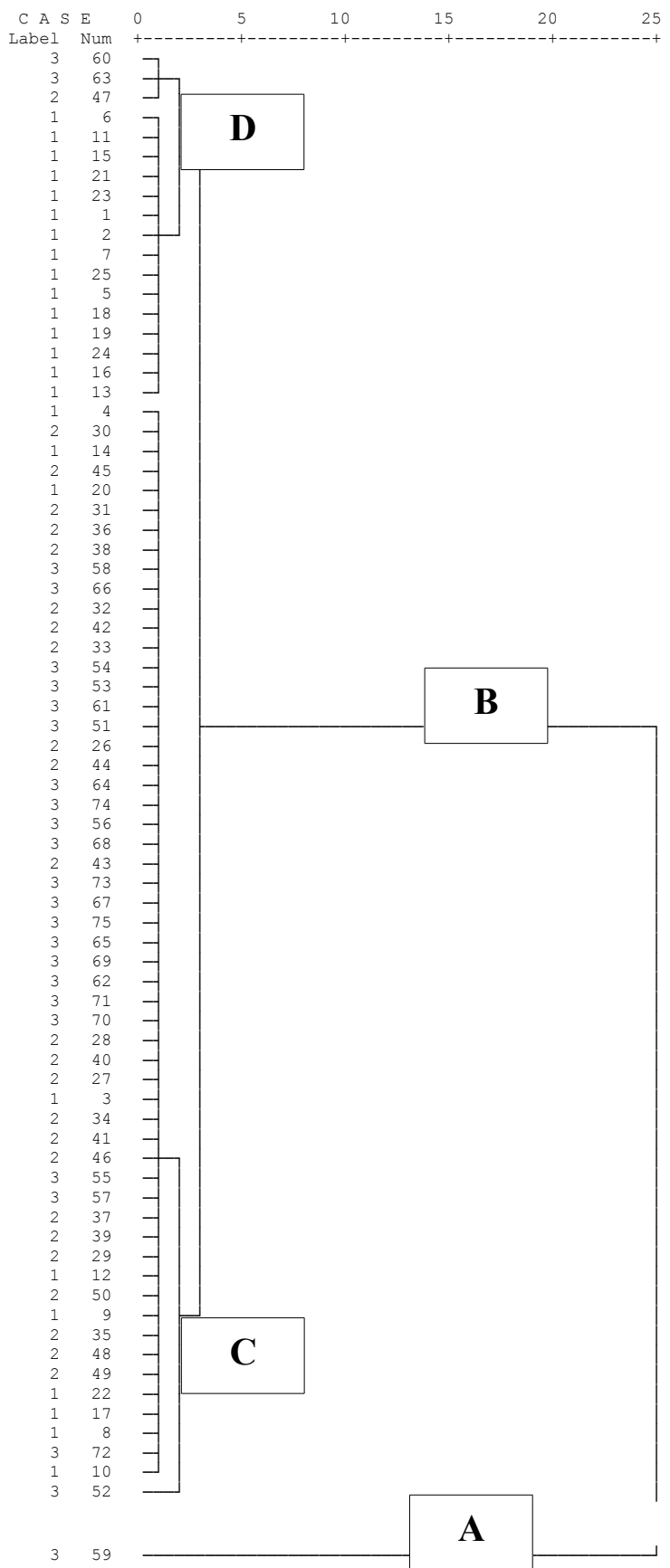

Ilustrasi 3. Dendogram 75 Tanaman Bawang Merah Varietas Bima Brebes Hasil Iradiasi Sinar Gamma. 
kelompok $\mathrm{C}$ yaitu tanaman nomor 52, tanaman kelompok D yaitu tanaman nomor 47, 60 dan 63 . Namun tanaman pada kelompok D merupakan tanaman yang mati, sehingga hanya terdapat dua nomor tanaman yang paling berpeluang untuk seleksi pada tahap selanjutnya yaitu tanaman nomor 59 dan 52. Tanaman nomor 59 dan 52 merupakan tanaman hasil dari penyinaran dosis 3 Gy. Hasil analisis karakter kuantitatif berupa dendogram tersaji pada Ilustrasi 3.

Analisis kekerabatan yang dilakukan dengan melakukan karakterisasi karakter kuantitatif, yaitu berdasarkan nilai ANR, kandungan klorofil a, klorofil $\mathrm{b}$ dan klorofil total $(\mathrm{a}+\mathrm{b})$, sedangkan karakter kuantitatif dikendalikan oleh banyak gen. Hal ini sejalan dengan Syahruddin (2012) bahwa karakter kuantitatif merupakan karakter yang tidak dapat dibedakan secara sederhana namun harus diukur dengan alat ukur tertentu yang hasilnya bersifat kuantitatif karena karakter kuantitatif dikendalikan oleh banyak gen. Hartati dan Darsana (2015) menyatakan bahwa keragaman dapat terjadi pada tingkat spesies yang disebabkan oleh faktor genetik dan lingkungan. Menurut Sari (2016) nilai keragaman yang dihasilkan cukup rendah $(<50 \%)$ disebabkan oleh genotipe berasal dari spesies yang sama dan dibudidayakan secara vegetatif.

\section{KESIMPULAN}

Hasil penelitian menunjukkan bahwa nilai $\mathrm{LD}_{50}$ penyinaran iradiasi sinar gamma untuk tanaman bawang merah adalah 7,64 Gy. Iradiasi sinar gamma (3 dan 6Gy) dapat meningkatkan kandungan klorofil a, klorofil $\mathrm{b}$, klorofil total $(\mathrm{a}+\mathrm{b})$ dan ANR bawang merah. Nilai heritabilitas bawang merah pada karakter klorofil a sebesar $52,22 \%$, klorofil b sebesar $53,21 \%$, klorofil total (a+b) 58,33\% dan ANR sebesar 80,51\%. Keragaman yang terbentuk pada dosis 6 Gy yaitu tanaman nomor 52 dan 59.

\section{DAFTAR PUSTAKA}

Abdel-Hady, M. S., E. M. Okasha, S. S. A. Soliman dan M. Talaat. 2008. Effect of gamma radiation and giberrelic acid on germination and alkaloid production in Atropa belladonna. Aust. J. Basic Appl. 2
(3) : 401-405.

Abdullah, T. L., J. Endan, dan B. M. Nazir. 2009. Changes in flower development chlorophyll mutation and alteration in plant morphology of Curcuma alismatifolia by gamma irradiation. American Journal of Applieed Sciences. 6 (7) : 1436 - 1439.

Aisyah, S. I. 2006. Induksi mutagen fisik pada anyelir (Dianthus caryophillus L.) dan pegujian stabilitas mutannya yang diperbanyak secara vegetatif. Disertasi. Sekolah Pasca Sarjana IPB, Bogor.

Banerji, B. K. dan S. K. Datta. 1992. Gamma ray inducesd flower shape mutation in Chrysanthemum cv 'Java'. J. Nuclear Agric. Biolo. 21 (2) : 73 - 79.

Batubara, A. U., Mariati, F. Ezra, dan T. Sitepu. 2015. Karakter pertumbuhan bawang merah (Allium ascalocum L.) varietas lokasl samosir pada beberapa dosis iradiasi sinar gamma. J. Online Agroekoteknologi 3 (1) : $246-434$.

Badan Pusat Statistik. 2015. Produksi, Luas Panen dan Produktivitas Sayuran di Indonesia. Badan Pusat Statistik dan Direktorat Jenderal Hortikultura, Jakarta.

Datta, S. K. 2001. Mutation studies on garden chrysanthemum. Sci. Horticulture. 7 (1) : $159-199$.

Departemen Pertanian. 2005. Prospek dan Arah Pengembangan Agribisnis Bawang Merah. Balai Penelitian dan Pengembangan Pertanian, Jakarta.

Ginting, J., N. Rahmawati, dan Mariati. 2015. Perubahan karakter agronomi bawang merah (Allium ascalonicum L.) aksesi simanindo samosir akibat pemberian berbagai dosis iradiasi sinar gamma. J. Online Agroekoteknologi. 3 (1) : 340 - 339.

Griffiths, A. J. F., S. R. Wessler, R. C. Lewontin, W. M. Gelbart, D. T. Suzuki dan J. H. 
Miller. 2005. Introduction to Genetic Analysis. WH. Freeman and Company, New York.

Hameed. A., T. M. Shah, dan B. M. Atta. 2008. Gamma irradiation effects on seed germination and growth, protein content, peroxidase and protease activity, lipid peroxidation in desi and kabuli chickpea. Pak. J. Bot. 40 (3) : 1033 - 1041.

Hartati, S., dan L. Darsana. 2015. Karakterisasi anggrek alam secara morfologi dalam rangka pelestarian plasma nutfah. J. Agron Indonesia. 43 (2) : 133 - 139.

Hartiko. 1987. Optimasi Metode Pengukuran Kegiatan Aktifitas Nitrat Reduktase In Vivo Daun Berbagai Spesies Tanaman Produksi. Laboratorium Biokimia, Fakultas Biologi Universitas Gadjah Mada, Yogyakarta.

Herison, C., Rustikawati, H. S. Surjono, S. I. Aisyah. 2008. Induksi mutasi melalui sinar gamma terhdap benih untuk meningkatkan keragaman populasi dasar jagung (Zea mays L.) Akta Agrosia. 11 (1) : 57 - 62.

Jusuf, M. 2001. Genetika I Struktur dan Ekspresi Gen. Sagung Seto, Jakarta.

Kadir, A., S. H. Sutjahjo, G. A. Wattimena, dan I. Mariska. 2007. Pengaruh sinar gamma pada pertumbuhan kalus dan keragaan planlet tanaman nilam. J. AgroBiogen. 3 (1) : 24 31.

Kim, J. H., B. Y. Chung, K. J. Sung, dan S. G. Wi. 2005. Effets of planta gamma-irradiaton on growth, photosynthesis and antioxidative capacity of red pepper (Capsicum annum L.) plants. J. Of Plant Biology. 48 (1) : 47 56.

Pellegrini, C. N., C. A. Croci, dan G. A. Orioli. 2000. Morphological changes induced by different does of gamma irradiation in garlic sprouts. Radiaton Physics and Chemistry. $57: 315-318$.
Pusat Data dan Sistem Informasi Pertanian. 2015. Outlook Bawang Merah. Pusat Data dan Sistem Informasi Pertanian, Kementrian Pertanian.

Permadi, A. H. 1995. Pemuliaan Bawang Merah: Teknologi Produksi Bawang Merah. Pusat Penelitian dan Pengembangan Hortikultura, Jakarta.

Rahimi, M. M., dan A. Bahrani. 2011. Influence of gamma irradtiation on some physiological characteristics and grain protein in wheat (Triticum aestivum L.) World Applied Science Journal. 15 (5) : $654-659$.

Sadhu, M. K. 1989. Plant Propagation. New Age International, New York.

Salisbury, F. B., dan C. W. Ross. 1995. Plant Physiology. 4rd Ed. Wadsworth Publissing Company. California.

Sari, N. K. Y., M. Pharmawati, dan I. K. Junitha. 2012. Pengaruh mutagen kimia sodium azida terhadap morfologi tanaman cabai besar (Capsicum annuum L.). J. Metamorf. $1(1): 25-28$.

Soeranto, H. 2003. Peran iptek nuklir dalam pemuliaan tanaman untuk mendukung industri pertanian. Prosiding Pertemuan dan Presentasi Ilmiah Peelitian Dasar Ilmu Pengetahuan dan Teknologi Nuklir P3TMBATAN Yogyakarta, 8 Juli 2003. Puslitbang Teknologi Isotop dan Radiasi, BATAN.

Sudrajat, D. J., dan M. Zanibar. 2009. Prospek teknologi iradiasi sinar gamma dalam peningkatan mutu benih tanaman hutan. Info Benih. $13: 158-163$.

Sugimoto, H., K. Kusumi, Y. Tozawa, J. Yazaki, N. Kishimoto, S. Kikuchi dan K. Iba. 2004. The virescent-2 mutation inhibition translation of plastid transcripts for the plastic genetic system at an early stage of chloroplast differentiation. Plant Cell Physiol. 45 (8) : 185 - 210. 
Sumenda, L., H. L. Rampe, dan F. R. Mantiri. 2011. Analisis kandungan klorofil daun mangga (Mangifera indica L.) pada tingkat perkembangan daun yang berbeda. J. Bioslogos. 1 (1) : $20-24$.

Sutarto, I., N. K. Dewi, dan Arwin. 2004. Pengaruh iradiasi sinar gamma 60 co terhadap pertumbuhan tanaman bawang putih (Allium sativum L.) varietas lumbu hijau di dataran rendah. Risalah Seminar Ilmiah Penelitian dan Pengembangan Aplikasi Isotop dan Radiasi, Jakarta.

Syahruddin, K. 2012. Analisis Keragaman Genetik Beberapa Genotipe Durian (Durio zibenthinus Murr.) Menggunkan Penanda Morfologi Dan Molekuler (ISSR). [Tesis].
Institut Pertanian Bogor, Bogor

Syukur, M., S. Sujiprihati, dan R. Yuniati. 2015. Teknik Pemuiaan Tanaman. Penebar Swadaya, Jakarta.

Thamrin, M., Ramlan, Armiati, Ruchjaningsih, dan Wahdania. 2003. Pengkajian sistem usahatani bawang merah di Sulawesi Selatan. J. Pengkajian dan Pengemb. Teknol. Pert. 6 (2) : 141 - 153

Wi, S. G., B. Y. Chung, dan J. S. Kim. 2007. Effects of gamma irradiation on morphological changes and biological responses in plants. Micron, 38 (2) : 553 564. 